\title{
25. HEAVY MINERALOGY OF UNCONSOLIDATED SANDS IN NORTHEASTERN PACIFIC SEDIMENTS: LEG 18, DEEP SEA DRILLING PROJECT
}

\author{
Kenneth F. Scheidegger and LaVerne D. Kulm, Oregon State University, Corvallis, Oregon; \\ and David J. W. Piper, Department of Geology. Dalhousie University, Halifax, N. S., Canada
}

\begin{abstract}
Immature, chemically unstable, pyroxene-amphibole heavy mineral assemblages characterize the unconsolidated sands from Leg 18. Sites 174A, 175, and 176 off the Oregon coast have received sediment from the upper portion of the Columbia River drainage system during glacial times. The heavy mineral composition of present-day Columbia River sands, dominated by sands from lower Columbia River sources, is not typical of what it has been in the past. Evidence for a change of sediment source was found in the lower part of Site $174 \mathrm{~A}$ and suggests that this site may have received sediments from more northerly or southerly sources two million years ago. Sands found at Site 177A have amphibole-rich assemblages except near basement where an epidote-rich assemblage is found. This drastic change in mineralogy at Site $177 \mathrm{~A}$, and the observed increased degree of etching of pyroxenes with depth at Sites 174A and 175, indicate that diagenesis is capable of modifying the character of heavy mineral assemblages. Heavy mineral analysis of sediments from the Gulf of Alaska (Sites 178-182) suggest that there is no evidence of a sediment source beyond the coast ranges of Alaska from middle Miocene to the present.
\end{abstract}

\section{INTRODUCTION}

Deposits of unconsolidated sands are common in sediments from all Leg 18 sites. Such coarse terrigenous sediments in the deep-sea environment are thought to represent the coarse fraction of turbidity current deposits that originated on, and were transported from, the unstable margins of neighboring continental land masses. As a prerequisite to understanding the nature of the provenance of the sediments at the various sites, a survey of the heavy mineralogy of the coarse-grained sediments was conducted. Heavy minerals in such deposits are usually characteristic of certain source rock lithologies.

Particular emphasis is placed on the heavy mineralogy of sands from Sites 174A, 175, and 176 off Oregon (Figure 1) because considerable work has been done on the heavy mineralogy of the potential sources of these sands (Kulm et al., 1968; Duncan and Kulm, 1970; Scheidegger et al., 1971). A primary objective is to determine if the sources of sediments found at these sites have remained constant through the stratigraphic sections. Ascertaining the provenance of sediments found at Site 177A off Vancouver Island and Sites 178 through 182 in the Gulf of Alaska is more speculative because relatively little work has been done on the mineralogy of neighboring continental sediment sources.

A secondary objective of this study is to describe and assess the importance of diagenetic changes of heavy mineral assemblages in the stratigraphic section. Although much is known about the mineralogy of marine sediments, relatively little is known about how this mineralogy can

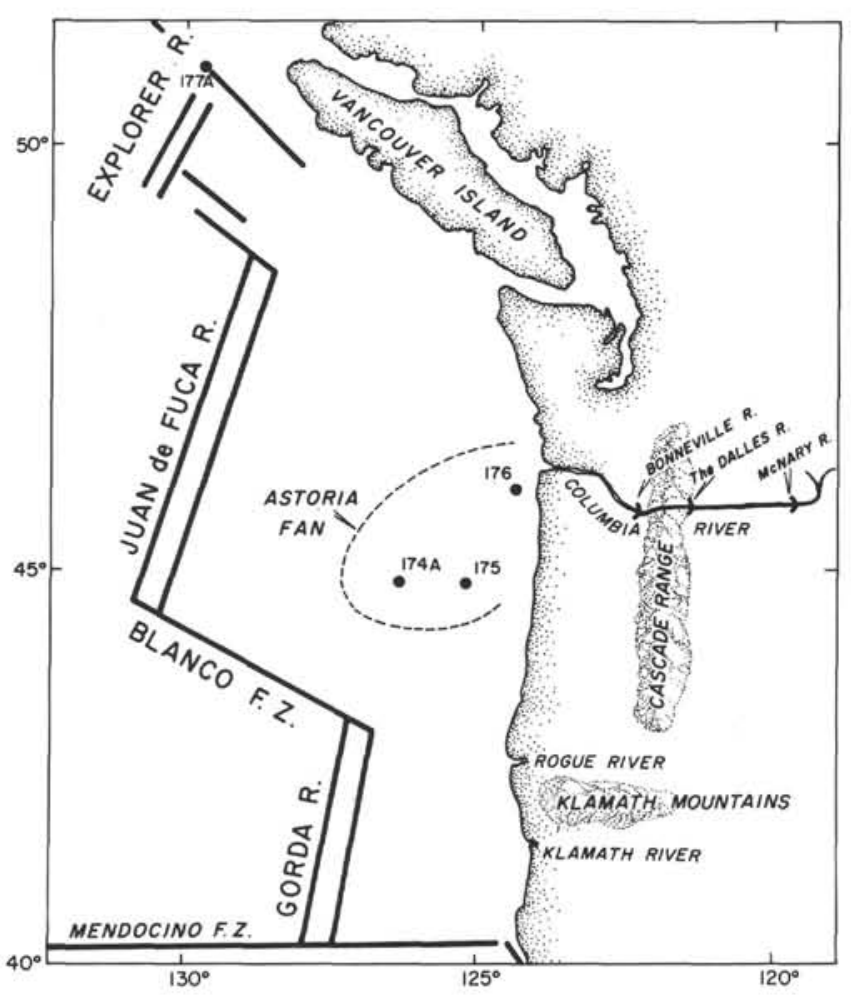

Figure 1. Submarine and continental features in the vicinity of DSDP Sites 174A, 175, 176 and $177 A$. 
change in response to processes acting within the sediment. At Sites 174A and 175, subtle changes in the character of the existing heavy mineral assemblages were noted, whereas, at Site $177 \mathrm{~A}$ the changes involved the formation of a distinctly different assemblage.

\section{METHODS OF ANALYSIS}

Samples of sand-sized sediments were obtained from the more prominent, coarser-grained deposits. Material finer than 62 microns was removed by wet sieving following ultrasonic disaggregation. The heavy mineral fractions of the sands were concentrated using tetrabromoethane (sp. gr. $=2.96)$ and were mounted in Aroclor (R.I. $=1.65$ ). Most samples were composed of very fine sands.

Out of more than 220 samples a total of 37 were selected for analysis. A quick preliminary investigation of all samples has revealed that our 37 samples can be considered to be representative of the heavy mineralogy of the sands. Sediment, both above and below the intervals sampled, showed similar mineralogy. One hundred or more nonopaque, nonmicaceous heavy minerals per sample were identified with a polarizing microscope. The results of the analyses are presented in Table 1 .

\section{HEAVY MINERALOGY OF SANDS}

Compositionally immature heavy mineral assemblages, dominated by relatively unstable amphiboles and pyroxenes and, to a lesser extent, by minerals of the epidote and garnet groups, characterize the heavy mineral composition of sands from Leg 18. The immature nature of the heavy mineral suites of these sands is similar to that of the consolidated, immature, feldspathic arenites described by Hayes (Chap. 29, this volume) for Sites 177A, 178 and 181.

\section{Sites off Oregon (174A-176)}

Subequal amounts of pyroxenes (principally augite and hypersthene) and amphiboles (principally blue green and green hornblende) with lesser amounts of garnet and epidote minerals characterize the heavy mineral assemblages found at these sites (see Table 1 and Figure 1). Other minerals, such as glaucophane, kyanite, staurolite, olivine, and zircon were usually present in trace amounts.

Trends among assemblages from Sites 175 and 176 are not evident. At Site 174A, there is a high degree of similarity between the heavy mineral assemblages above Core 34 and those present at Sites 175 and 176. Clearly, there is no reason to consider that these samples are not part of a single population. Below Core 34 , at about 370 meters, however, the heavy mineralogy of the samples changes significantly to an amphibole-rich assemblage with little clinopyroxene and hypersthene. Only in the section below Core 34 at Site $174 \mathrm{~A}$ is there any indication of a change in sediment source.

Work by Duncan and Kulm (1970) and others indicate that the source of sediments found at Sites 174A, 175, and 176 should be the Columbia River. This is logical since Site 176 is close to the mouth of the Columbia and Sites 174A and 175 contain typical fan-like deposits which have heavy mineral assemblages that are similar to those found in piston cores taken from Astoria Fan (see Figures 1 and 2).
Duncan and Kulm (1970) have shown that the Columbia River is the source of sediments found on Astoria Fan.

Although the heavy mineral assemblages from Sites 174A, 175, and 176 and Columbia River-derived sediments on Astoria Fan are similar, it is rather paradoxical to note that present day Columbia River sediments are notably more pyroxene-rich and perhaps more epidote-garnet poor than are those found on Astoria Fan and at Sites 174A, 175, and 176 (see Figure 2). Work by Whetten et al. (1969) has shown that such pyroxene-rich assemblages from the lower Columbia and from the Dalles and Bonneville reservoirs reflect the significant contribution of pyroxenerich detritus from Oregon's and Washington's Cascade Range (see Figure 1). Evidently, the heavy mineral suites of the Columbia River sands that are being carried to the ocean at the present time are not typical of what it transported in the past. Whetten et al. (1969) have also presented heavy mineral data for sands from the upper Columbia River reservoirs. Heavy minerals found in sands from McNary Reservoir, which lies just downstream from the confluence of the upper Columbia and Snake rivers and thus should contain sands that are most representative of the coarse detritus being eroded from the upper part of the Columbia River drainage system, are quite similar to those found in Astoria Fan sands (see Figure 2). Clearly, the upper Columbia River drainage system must have been a more important source of sediments during glacial times than the lower Columbia drainages. This conclusion is in agreement with the work of Duncan et al. (1970) who show a temporal change in clay mineralogy of Columbia River sediments during glacial and interglacial times.

It is not possible, however, to attribute the transition from an amphibole-pyroxene assemblage in the upper portions of Site $174 \mathrm{~A}$ to an amphibole assemblage below to variations in mineralogy of Columbia River sediments. Below Core $34(370 \mathrm{~m})$, very little clinopyroxene and hypersthene were observed. One would not expect these minerals to be impoverished in Columbia River sediments because extensive outcrops of basic igneous rocks are present in its drainage system. It is conceivable that such a mineralogy change could be the result of a slightly finer grain size of the sands below Core 34. However, the observation that similar very fine sands from Core 33 have pyroxene-rich heavy mineral assemblages makes it very unlikely that the mineralogical differences can be the result of selective sorting effects. Diagenesis was considered as a cause of the mineralogy differences but rejected because chemically unstable minerals, such as amphiboles and clinopyroxenes, were abundant. Although the pyroxenes in the sands from the lower part of Site $174 \mathrm{~A}$ are quite etched, they are still sand-sized grains. It is evident that etching has not been responsible for their relative scarcity. The subtle effects of etching observed on pyroxenes found at Site $174 \mathrm{~A}$ and 175 are discussed in detail below.

The most logical explanation for the change in heavy mineralogy found at Site $174 \mathrm{~A}$ is that the sources of sediment were different at an earlier time. Previous studies by Kulm et al. (1968) and Scheidegger et al. (1971) suggest that the amphibole dominant assemblage in the lower portion of Site 174A is similar to the heavy mineralogy of the Klamath and Rogue rivers (Figures 1 and 2), the two 
HEAVY MINERALOGY OF UNCONSOLIDATED SANDS, NORTHEASTERN PACIFIC SEDIMENTS

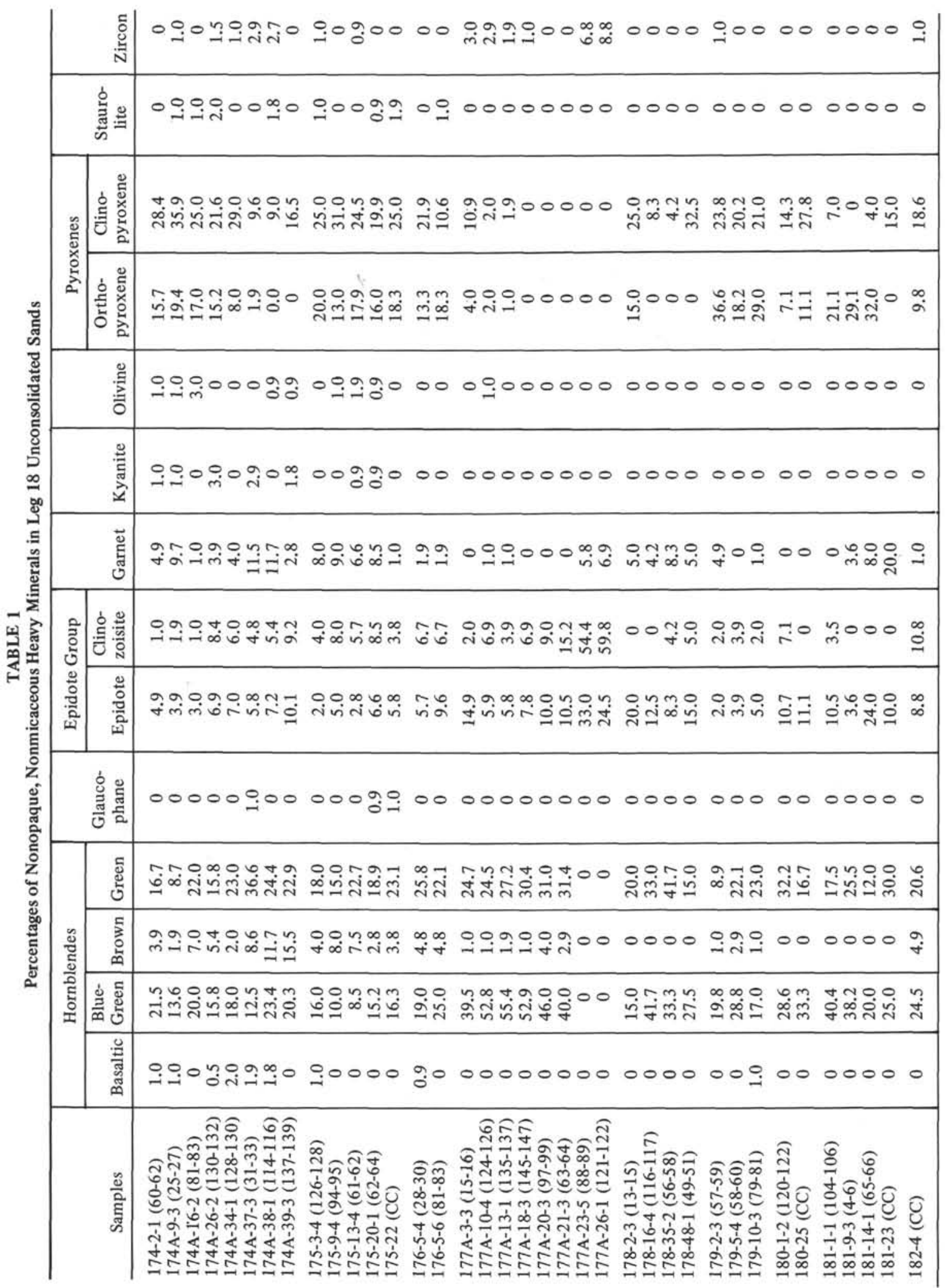

largest rivers draining the largely metamorphic terrane of the Klamath Mountains of southern Oregon and northern California. Although the Klamath and Rogue rivers have less epidote and garnet minerals than those from the lower part of Site $174 \mathrm{~A}$, many of the smaller drainages within the
Klamath Mountain provenance are rich in these components (Kulm et al., 1968). Admixture of sediments from the various river drainages may have created a heavy mineral assemblage that is like those from Cores 37,38 , and 39 of Site 174A. Another potential source of these sands 


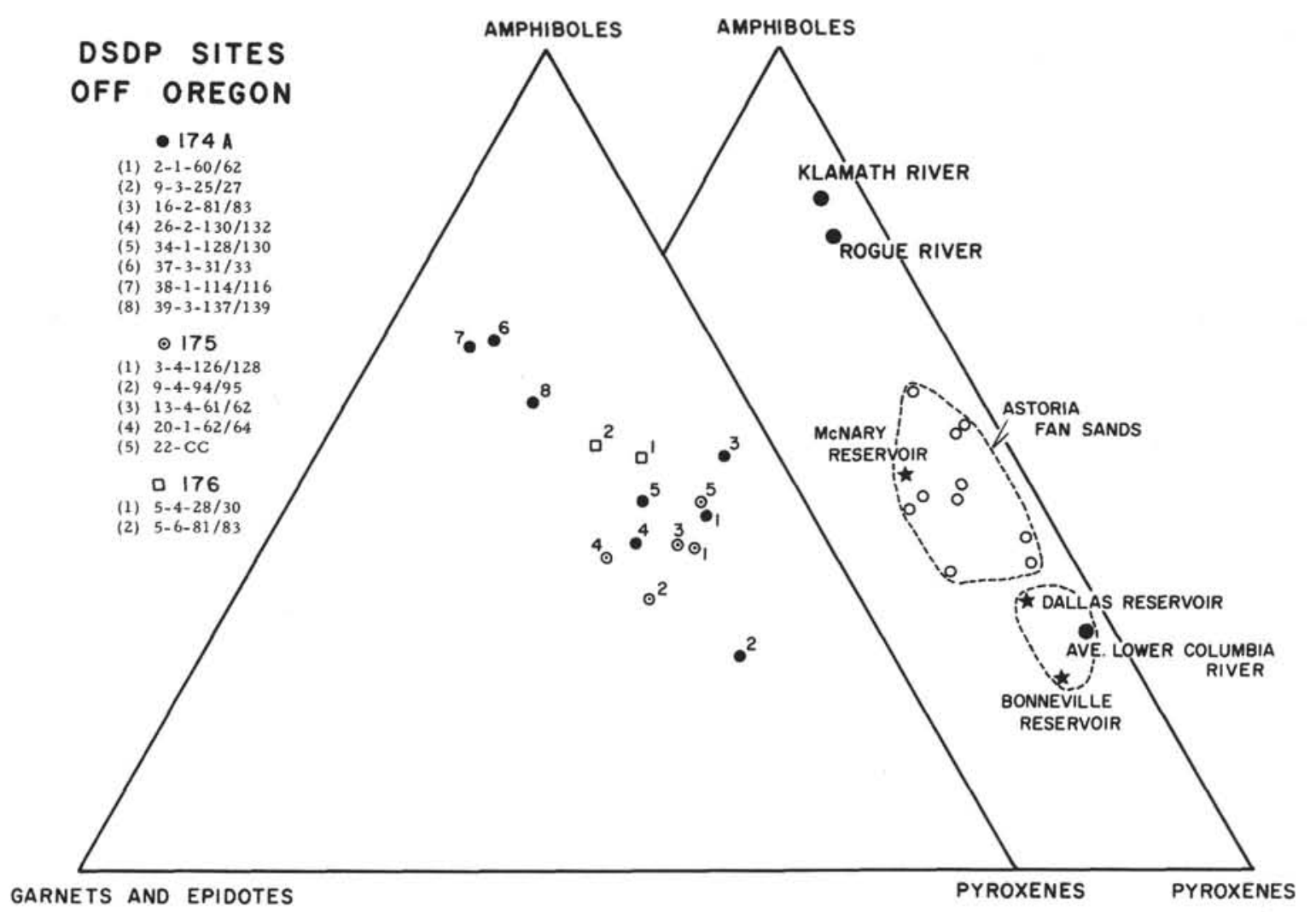

Figure 2. Triangular diagrams of heavy mineral assemblages of sands from DSDP sites off Oregon and from Astoria Fan. Data on heavy mineral assemblages from major rivers contributing sands to the deep-sea environment off Oregon and from reservoirs on the Columbia River are shown for comparison.

may be the hornblende-rich sediments that are derived from coastal drainages of Vancouver Island and British Columbia (Easterbrook, 1963; Wiese, 1969; Carter, 1970). Sands from Site $177 \mathrm{~A}$, which have apparently been derived from such a hornblende-rich source, are similar to those found in the lower part of Site 174A (compare Figures 2 and 3). In addition, the clay mineralogy from the lower part of Site $174 \mathrm{~A}$ and the upper part of Site 177A are similar (see Zemmels, this volume). If the sources of sediments found in the lower part of $174 \mathrm{~A}$ were either the Klamath Mountains to the south or the Vancouver Island area to the north, it is possible that the Site $174 \mathrm{~A}$ area occupied a different geographical position and was not sedimentary province receiving sediment from the Columbia River. According to Atwater (1970) and Silver (1971), the Juan de Fuca Plate has been moving in a counterclockwise sense relative to North America. Two million years ago, Site 174A would have been about $100 \mathrm{~km}$ to the southwest and in closer proximity to the Klamath Mountain provenance. If, on the other hand, the Juan de Fuca Plate has been coupled to North America (see Tectonic Summary, von Huene and Kulm, Chapter 33, this volume) one would expect Site $174 \mathrm{~A}$, which is moving away from the Juan de Fuca Ridge at a rate of about $2.9 \mathrm{~cm} / \mathrm{yr}$ (Vine, 1966), to have occupied a position about $58 \mathrm{~km}$ to the northwest 2 my ago. Such a displacement would have brought Site $174 \mathrm{~A}$ close to a sedimentary province that has received sediments from more northerly Vancouver Island-British Columbia sources
(Duncan and Kulm, 1970). Although heavy mineral analysis alone does not eliminate either of these models, it does suggest the possibility that Site $174 \mathrm{~A}$ entered the Columbia River sedimentary province about 2 my ago from either a southerly or westerly direction.

\section{Site off Vancouver Island (177A)}

The heavy mineral assemblages found at Site $177 \mathrm{~A}$ are the most unusual of any investigated from Leg 18. With the exception of the sands from below Core 21, these suites can be characterized as amphibole assemblages with subordinate amounts of minerals of the epidote group (see Figure 3 and Table 1). Blue green hornblende is the dominant type of amphibole. Between Core 21, Section 3 and Core 23, Section 5, a drastic change in the assemblages is evident. The heavy mineral suites of sands from Cores 23 and 26 consist almost totally of minerals of the epidote group, namely epidote and clinozoisite. Other minerals identified from this lower section include garnet and zircon. It is clear that the heavy mineral assemblages found in the lower section of Site 177A are chemically more stable and mature than those found in the upper section.

Potential sources of sediments found at Site 177A include the neighboring land masses of Vancouver Island and western British Columbia. Wiese (1969) has reported amphibole-rich assemblages from the northern end of Vancouver Island in Queen Charlotte Sound and Carter (1970) has found that relict sediments on the shelf off 


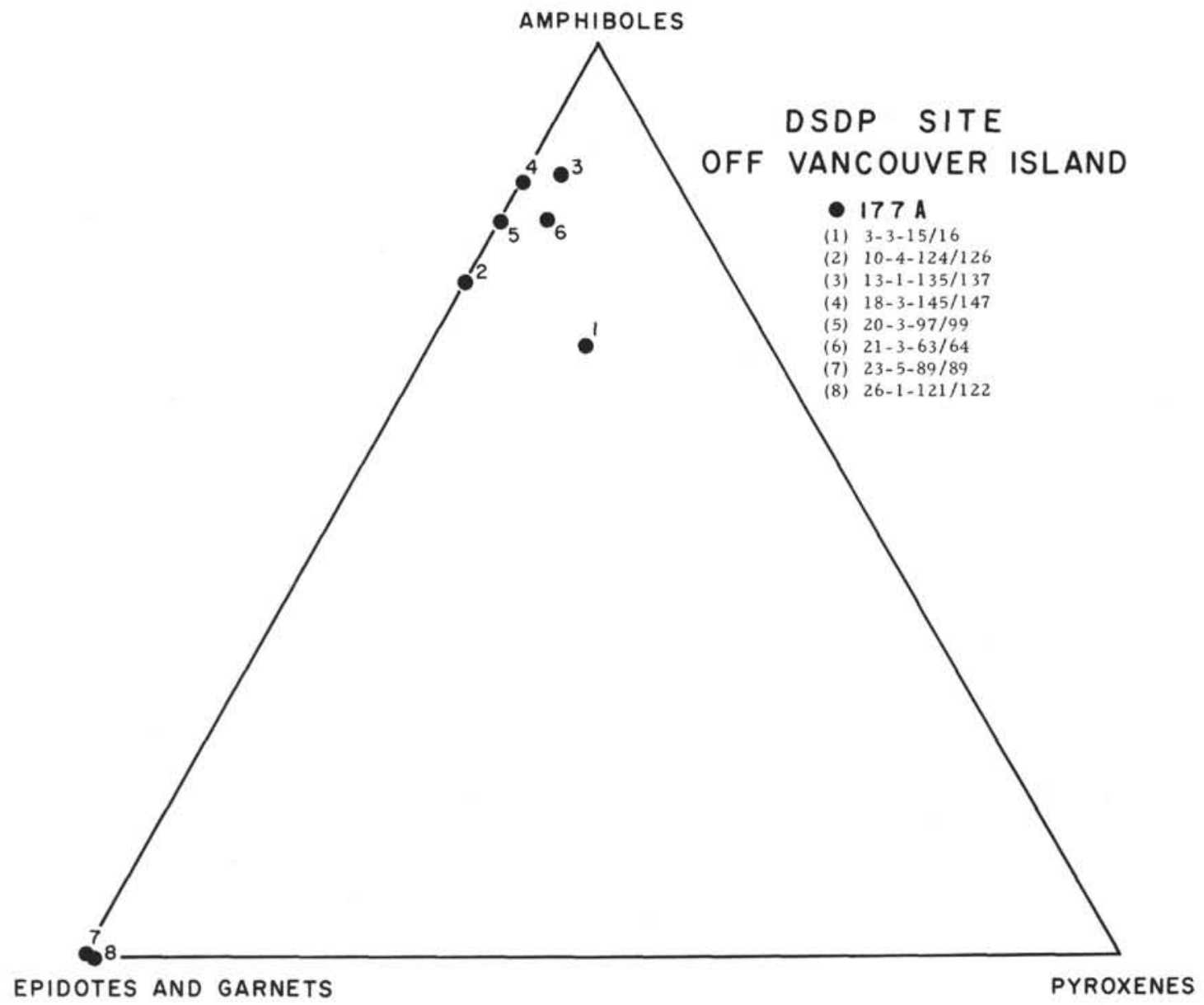

Figure 3. Triangular diagram of heavy mineral assemblages found in sands from Site $177 \mathrm{~A}$ off Vancouver Island.

Vancouver Island are rich in hornblende and epidote. Similarly, Easterbrook (1963) has suggested that heavy minerals derived from British Columbia are characterized by a high content of hornblende. Since sands derived from the potential sediment sources are quite amphibole-rich, it is clear that these neighboring land masses supplied the amphibole-rich sands found in the upper portion of Site $177 \mathrm{~A}$.

Difficulties arise when one attempts to explain the change in the lower Pliocene from an amphibole assemblage (above $272 \mathrm{~m}$ ) to an epidote assemblage (below $352 \mathrm{~m}$ ). A change in provenance is a possible explanation for the observed mineralogy differences although it is difficult to reconcile this with what is known about the present geology of neighboring land masses and the sediments that are derived from them. The coast mountains of British Columbia consist largely of granodiorites, quartz diorites and diorites with associated schists and gneisses (Easterbrook, 1963). Sediment studies by Easterbrook (1963), Wiese (1969), Carter (1970) and Carson (1971) indicate that heavy mineral assemblages of sands found in the vicinity of Site 177A are characteristically rich in amphiboles. Even if progressive denudation of a continental sediment source can cause a stratigraphic succession of heavy mineral assemblages in neighboring sediment deposits (Krynine, 1942), one would not expect amphiboles to be totally absent in any heavy mineral assemblage derived from the progressive denudation of such a complex and varied source rock terrane. The possibility exists that the onset of glaciation on the neighboring continental sediment sources caused a greater influx of chemically unstable, amphibole-rich heavy minerals to the deep-sea environment. However, since the change in mineralogy occurred in the lower Pliocene, this appears to preclude this explanation. Weathering of unstable heavy minerals prior to deposition could have significantly altered the heavy mineral assemblages (van Andel, 1959) because epidote is slightly more resistant to weathering than hornblende. This possibility cannot be eliminated although it is strange that no weathered or unweathered grains of hornblende were observed from the lower part of Site 177A. Selective sorting is also capable, in certain instances, of creating an epidote assemblage from an amphibole-pyroxene-epidote assemblage (van Andel, 1959). However, van Andel also showed that epidotes and hornblendes have nearly the same densities and similar size distributions. Since their hydrodynamic behavior is probably quite similar, it is difficult to envision how a sedimentary process could so effectively sort these heavy mineral species. On the basis of this discussion, it seems that the observed changes in mineralogy has not been caused by changes in sediment source or by processes acting on the sediments prior to deposition. Clearly, it is highly probable that diagenetic processes acting within the sediments have been responsible for the 
formation of an epidote-rich assemblage in the lower part of Site 177A. This proposed explanation of the mineralogy differences is examined below.

\section{Sites in Gulf of Alaska (178-182)}

About ninety heavy mineral separations of grains coarser than 44 microns from sands and coarse silts from Sites 178 through 182 have been examined. With the exception of about ten samples from ash beds and biotite-rich layers, most samples can be grouped into the following two assemblages:

1) An assemblage with abundant hornblende and hypersthene that was found in the upper part of Site 178, all of 179 and 180 , at least the upper fourteen cores of 181 , and probably all of 182 .

2) An assemblage with abundant hornblende and almost no hypersthene in the lower part of Site 178 down to at least Core 49. The boundary between the two assemblages in Site 178 is gradational, but probably falls between Cores 12 and 26 . Pinpointing the boundary is hampered by the lack of suitable material in this interval. Other than in hypersthene content, the two assemblages are similar (see Figure 4 and Table 1). They appear to have been derived from a low or medium grade metamorphic source with some basic or intermediate crystalline rocks. There is thus no evidence of a source beyond the coast ranges of Alaska from middle Miocene time to the present.

\section{EVIDENCE OF INTRASTRATAL SOLUTION FROM HEAVY MINERAL ASSEMBLAGES}

Heavy mineral assemblages, such as those from Leg 18 that contain high percentages of chemically unstable augites and hornblendes (Pettijohn, 1957), should be particularly sensitive to the effects of intrastratal solution. The high porosity of individual sand layers, which initially may have been about 35 to 40 percent (Hays, Chap. 9, this volume), probably allowed fluids to circulate freely through rather than across individual layers. Each sand layer is generally bounded both above and below by relatively impermeable hemipelagic clays. During our preliminary investigation of the heavy minerals found in these layers, we noted both subtle changes in the morphology of individual grains as well as drastic changes of the heavy mineral suites. Our findings are in agreement with Pettijohn's (1957) suggestion that intrastratal solution may be capable of modifying heavy mineral assemblages. In the following discussion, the effects that were noted are described. Failure to recognize the more drastic intrastratal solution effects could make it impossible to determine the actual provenance of a deposit.

\section{Site $\mathbf{1 7 5}$}

Sands from Site 175 contain high percentages of amphiboles, clinopyroxenes, and orthopyroxenes at all stratigraphic levels. While performing the heavy mineral counts, it was noted that the degree of etching of both clinopyroxenes and orthopyroxenes increased with increasing depth in the section (see Plate 1). This same effect was noted for Site 174A. To quantify the observations, sixteen heavy mineral slides of samples from different stratigraphic levels at Site 175 were selected and thoroughly mixed. A slide was then randomly selected and the first thirty hypersthene grains observed were ascribed to unetched, slightly etched, moderately etched, and extremely etched categories. Hypersthene was selected for study because it is easy to identify and because it is usually found as euhedral to subhedral prismatic crystals. In Figure 5, the results of this investigation are shown. Because of the subjectivity of ascribing an individual hypersthene to a particular category and of the inherent variability of small sample sizes, much scatter exists. However, if one assigns each successive stratigraphic group of four samples to a class, it is clearly evident that the degree of hypersthene etching increases with depth in the section.

The significance of hypersthene and clinopyroxene. etching is that if a sand layer remains open to the circulation of intrastratal solutions, both of these components will ultimately disappear from its heavy mineral assemblage. Sediments deposited at Site 175 are younger than 1.85 my and those from Site 174A are younger than 5 my. From our petrographic studies, it is evident that for the geologic times reached in Sites 174A and 175, intrastratal solution has not seriously modified the heavy mineral assemblages. However, if intrastratal solution were allowed to continue for perhaps $10 \mathrm{my}$ at the rate it has for the last 2 my, the character of the resulting heavy mineral assemblages would be significantly altered. One would not see any evidence in the heavy mineral assemblages for the presence of basic igneous rocks in the source rock terrane.

\section{Site 177A}

As discussed above, it appears unlikely that the transition from a chemically unstable amphibole heavy mineral assemblage to a more stable epidote assemblage below Core 21 has been caused by a change in provenance or by other processes acting on the sands prior to deposition. The formation of a nearly monomineralic epidote assemblage by these means would require geologically unreasonable circumstances for this area of British Columbia.

A more plausible explanation for the change in mineralogy is that the character of the heavy mineral assemblages has been significantly altered by processes acting within the sediments subsequent to their deposition. The observed change in mineralogy below Core 21 is analogous to the change in heavy mineral assemblages between the calcareous concretions and the surrounding matrix of a sandstone from California (Bramlette, 1941). Bramlette showed that the calcareous concretions of this sandstone had 44 percent hornblende whereas the matrix had 5 percent and was notably enriched in epidote minerals. This difference in mineralogy was attributed to leaching of the amphiboles from the matrix by circulating intrastratal solutions. At Site $177 \mathrm{~A}$, it is possible that the relative enrichment of epidote, garnet, and zircon has been caused by such preferential dissolution of amphiboles since there is an indication these three components have similar relative abundances both above and below Core 21 (see Table 1). In addition, Hayes (this volume) has suggested the possibility diagenetic chlorite has replaced amphiboles in the sandstones from the lower portion of Site 177A. Hayes has also suggested that permeating acidic fluids have subsequently dissolved some 


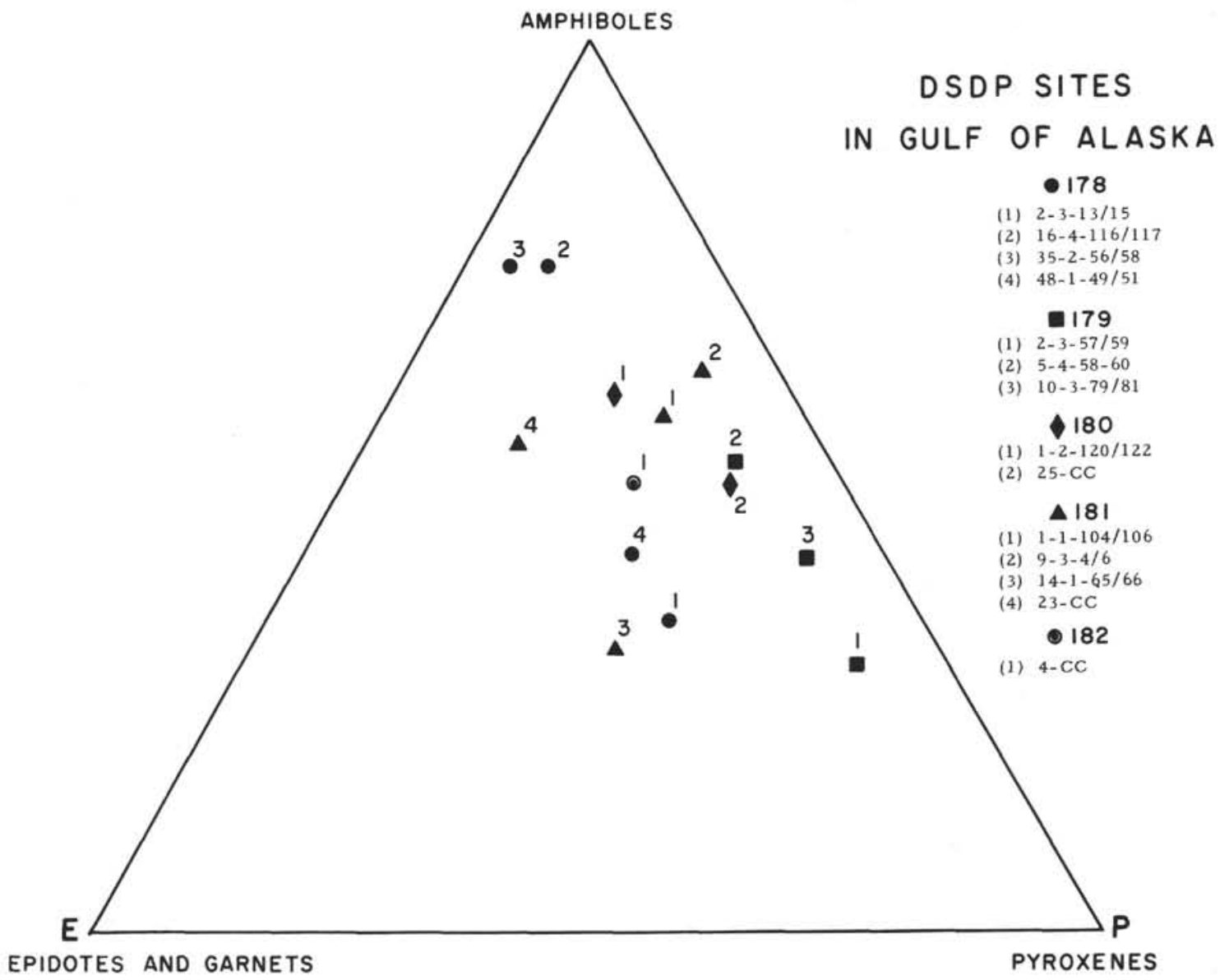

Figure 4. Triangular diagram of heavy mineral assemblages found in sands from DSDP sites in Gulf of Alaska.

of this diagenetic chlorite and other constituents, thereby creating the patchy porosity observed in the sandstones. Conceivably, such chemically active intrastratal solutions could have totally dissolved the diagenetic chlorite as well as other constituents. The net effect of this may have been the creation of unconsolidated sands with epidote-rich heavy mineral assemblages. Our limited data do not enable us to distinguish between preferential dissolution of amphiboles or replacement of amphiboles by chlorite followed by dissolution of the chlorite. Nevertheless, it is logical that diagenetic processes have dramatically altered the heavy mineral assemblages below Core 21 .

\section{CONCLUSIONS}

1. Immature, pyroxene-amphibole assemblages characterize the heavy mineralogy of sands found at all Leg 18 sites.

2. Except for sands found in the lower part of Site $174 \mathrm{~A}$, where either a more northerly or southerly source is indicated, all sand deposits found at Sites 174A, 175, and 176 have come from the Columbia River.

3. Present-day Columbia River sands have heavy mineral assemblages that are not typical of the sands it transported during the Pleistocene. During glacial times large quantities of amphibole-rich sediments were derived from upper Columbia River drainages and they dominated the pyroxene-rich assemblages carried by rivers draining the Cascade Range of Oregon and Washington.

4. Heavy mineral analysis of sands found at Site 177A off Vancouver Island and Sites 178 through 182 in the Gulf of Alaska suggest that the neighboring coast ranges of British Columbia and Alaska, respectively, have been the sediment sources.

5. At Site 175 , the degree of pyroxene etching increases with depth in the hole and points to the partial dissolution of these unstable minerals by circulating intrastratal fluids. At Site $177 \mathrm{~A}$, the transition from an immature, amphibole assemblage to a relatively mature, epidote heavy mineral assemblage has been attributed to the selective removal of chemically unstable minerals by diagenetic processes.

\section{ACKNOWLEDGMENTS}

We wish to thank Drs. G. Ross Heath and John B. Hayes for reviewing the manuscript and for making suggestions for its improvement. A special thank you is extended to Miss Sallie Hee and Mrs. Carol Lantz for preparing numerous heavy mineral slides.

\section{REFERENCES}

Atwater, T., 1970. Implications of plate tectonics for the Cenozoic tectonic evolution of western North America. Bull. Geol. Soc. Am. 81, 3513. 


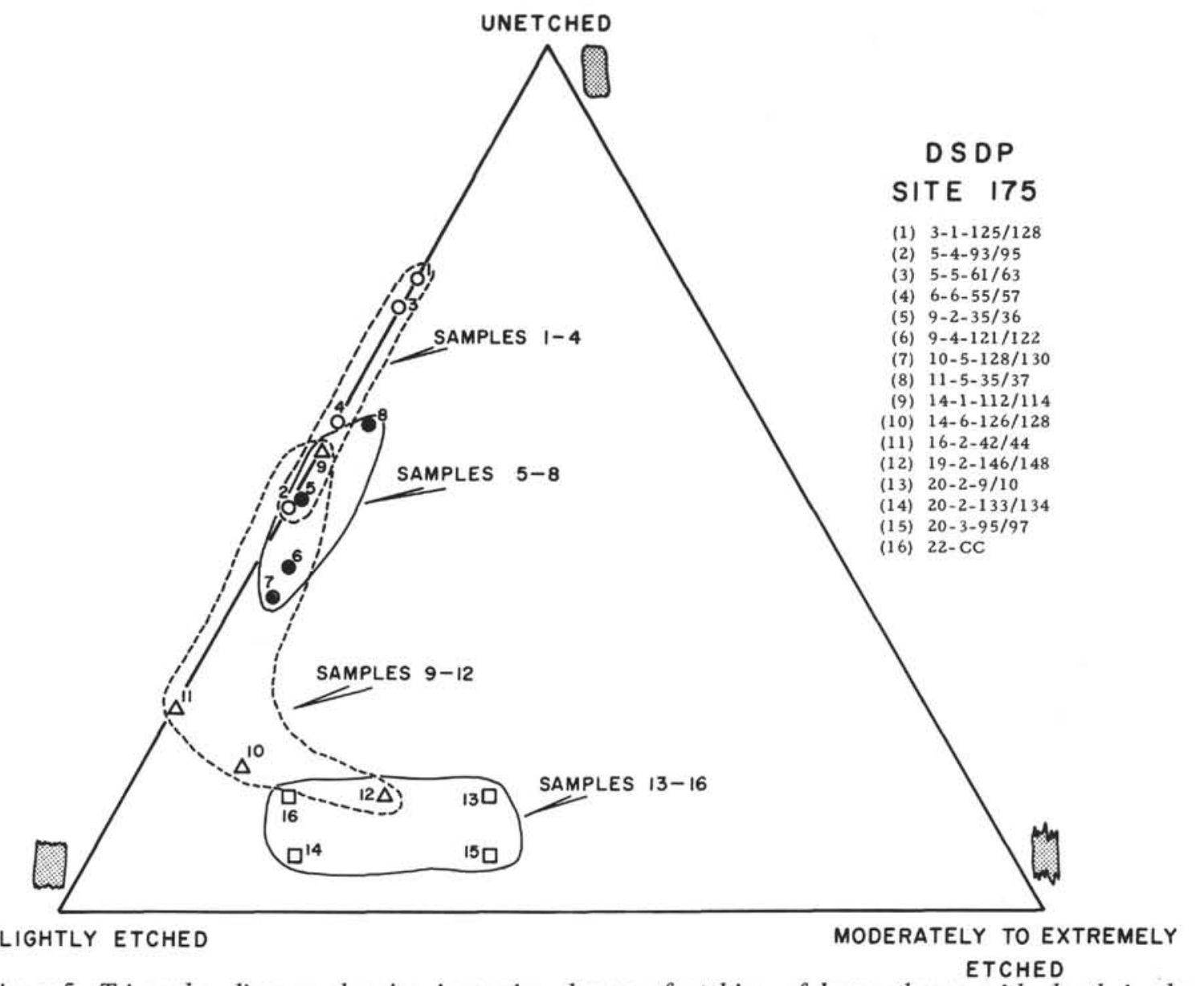

Figure 5. Triangular diagram showing increasing degree of etching of hypersthenes with depth in the stratigraphic section at Site 175.

Bramlette, M. N., 1941. The stability of heavy minerals in sandstone. J. Sediment. Petrol., 11, 32.

Carter, L., 1970. Surficial sediments in Barkley Sound and adjacent continental shelf. Ph.D. Dissert., University of British Columbia, Vancouver, Canada.

Carson, B., 1971. Stratigraphy and depositional history of Quaternary sediments in northern Cascadia Basin and Juan de Fuca Abyssal Plain, northeast Pacific Ocean. Ph.D. Dissert., University of Washington, Seattle, Washington.

Duncan, J. R. and Kulm, L. D., 1970. Mineralogy, provenance, and dispersal history of late Quaternary deep-sea sands in Cascadia Basin and Blanco Fracture Zone off Oregon. J. Sediment. Petrol. 40(3), 874.

Duncan, J. R., Kulm, L. D. and Griggs, G. B., 1970. Clay mineral composition of late Pleistocene and Holocene sediments of Cascadia Basin, northeastern Pacific Ocean. J. Geol. 78(2), 213.

Easterbrook, D. J., 1963. Late Pleistocene glacial events and relative sea level changes in the northern Puget Lowland, Washington. Bull. Geol. Soc. Am. 74, 1465.

Krynine, P. D., 1942. Differential sedimentation and its products during one complete geosynclinal cycle. 1st Panamerican Congress Mining Engr. and Geol. Proc. 2, 537.
Kulm, L. D., Scheidegger, K. F., Byrne, J. V. and Spigai, J. J., 1968. A preliminary investigation of the heavy mineral suites of the coastal rivers and beaches of Oregon and northern California. Ore Bin. 30, 165.

Pettijohn, F. J., 1957. Sedimentary rocks. 2nd Ed. New York. (Harper and Brothers) $718 \mathrm{p}$.

Scheidegger, K. F., Kulm, L. D. and Runge, E. J., 1971. Sediment sources and dispersal patterns of Oregon continental shelf sands. J. Sediment. Petrol. 41(4), 1112.

Silver, E. A., 1971. Small plate tectonics in the northeastern Pacific. Bull. Geol. Soc. Am. 82, 3491.

van Andel, Tj. H., 1959. Reflections on the interpretation of heavy mineral analyses. J. Sediment. Petrol. 29(2), 153.

Vine F. J., 1966. Spreading of the ocean floor: New evidence. Science. 154, 1405.

Whetten, J. T., 1966. Sediments from the lower Columbia River and origin of graywacke. Science. 152, 1057.

Whetten, J. T., Kelley, J. C. and Hanson, L., 1969. Characteristics of Columbia River sediment and sediment transport. J. Sediment. Petrol. 39(3), 1149.

Wiese, W., 1969. Studies in properties, distribution, and heavy mineral contents of sediments in northern Queen Charlotte Sound. B. Sc. Thesis, University of British Columbia, Vancouver, Canada. 



\section{PLATE 1}

Figures A, B, C Unetched hypersthenes. 175-5-5 (61-63 cm). Depth in section is 40.1 meters.

Figures D, E, F Unetched and slightly etched hypersthenes. 175-9-4 $(121-122 \mathrm{~cm})$. Depth in section is 77.0 meters.

Figures G, H, I Slightly etched hypersthenes. 175-14-6 (126-128 cm). Depth in section is 127.6 meters.

Figures J, K, L Slightly and moderately etched hypersthenes. $175-20-3(95-97 \mathrm{~cm})$. Depth in section is 179.9 meters. 
HEAVY MINERALOGY OF UNCONSOLIDATED SANDS, NORTHEASTERN PACIFIC SEDIMENTS

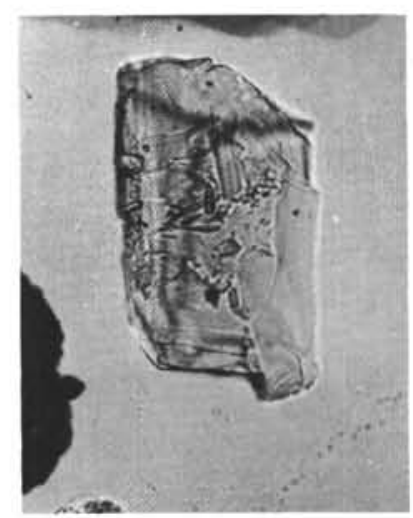

A

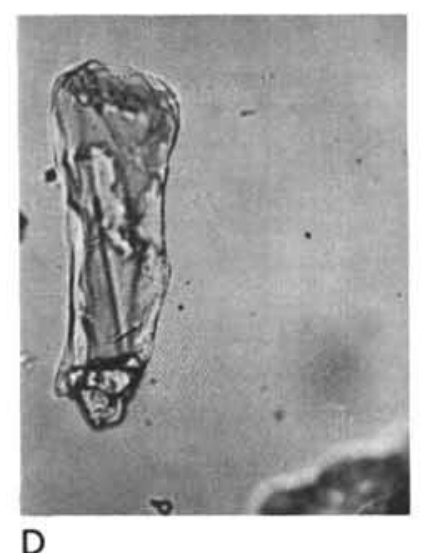

D

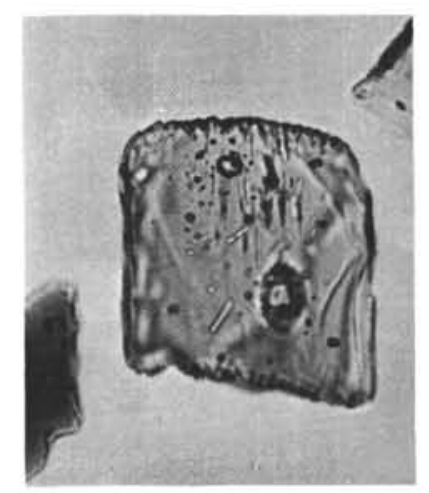

G

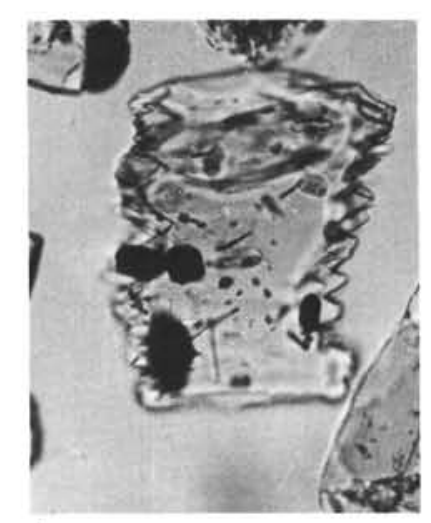

J
PLATE 1

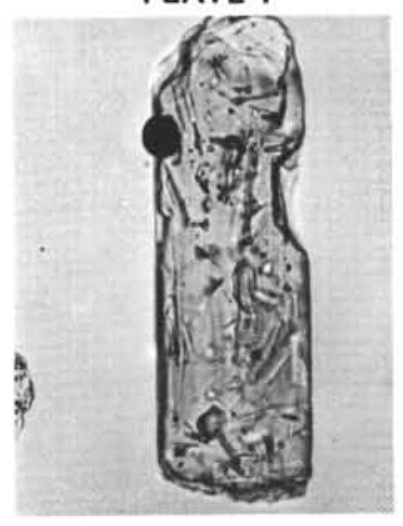

B

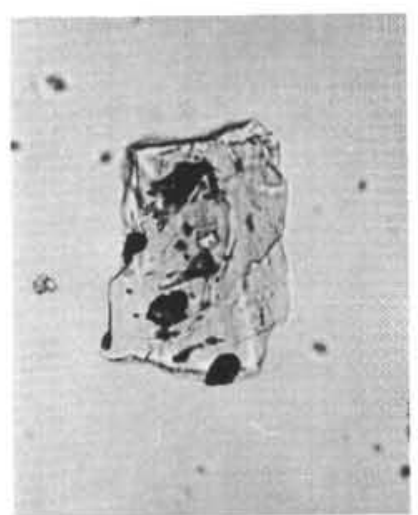

$E$

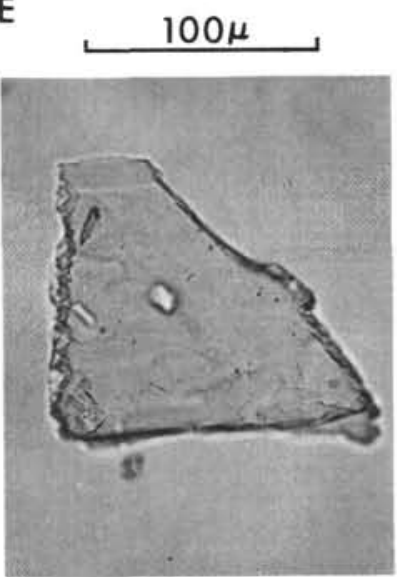

$\mathrm{H}$

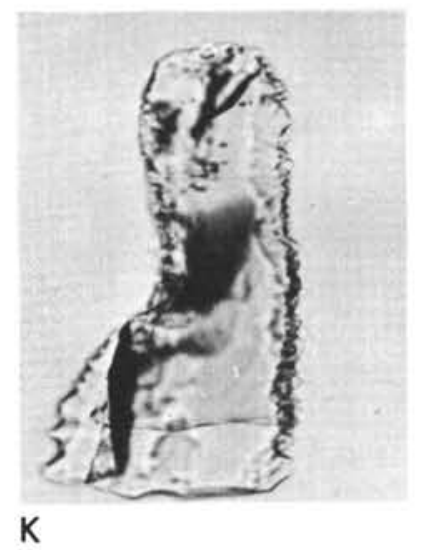

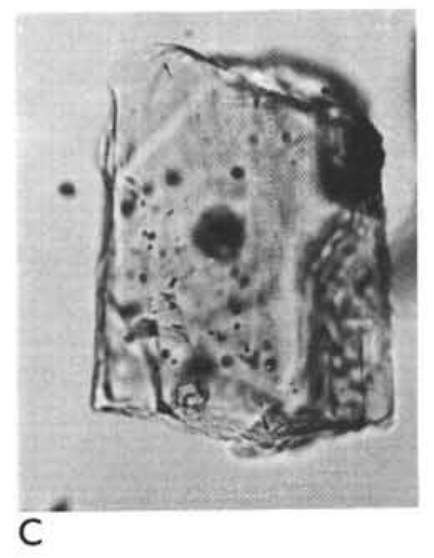

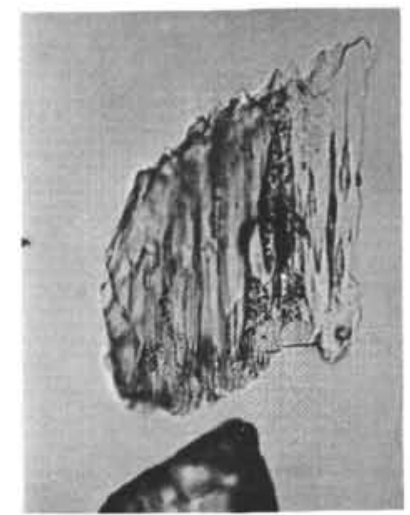

$\mathbf{F}$
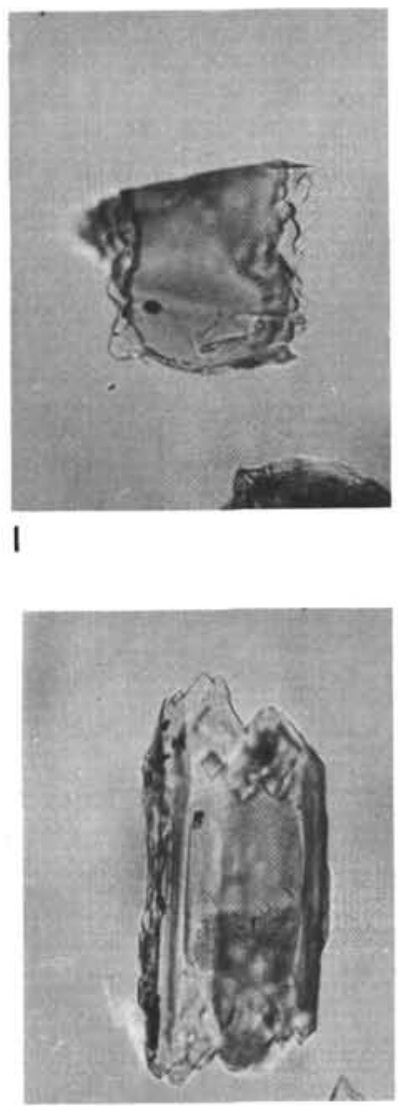

L 